\title{
Delta Opioid Receptor mRNA Distribution in the Brain: Comparison to Delta Receptor Binding and Proenkephalin mRNA
}

\author{
Alfred Mansour*, Robert C. Thompson, Huda Akil and Stanley J. Watson \\ Mental Health Research Institute and Department of Psychiatry. University of Michigan. Ann Arbor. MI 48109. (0720, \\ USA
}

\begin{abstract}
The recent cloning of the mouse delta opioid receptor (Evans 't al. 1992; Kieffer 't al., 1992) has demonstrated it to be a member of the seven transmembrane G-protein coupled family of ncurotransmitter receptors. The present study describes the cellular localization in the central nervous system (CNS) of an mRNA encoding this receptor and compares it with the distribution of delta receptor binding and proenkephalin mRNA using a combination of in situ hybridization and receptor autoradiographic techniques. Delta receptor mRNA was visualized with a cRNA probe $(472903 \mathrm{bp})$ corresponding to transmembrane domains $I I I-V I$ of the receptor, while proenkephalin mRNA was labeled with a cRNA probe to exon $3(139-8.32 \mathrm{bp})$. A high level of correspondence was observed between the distribution of delta receptor $\mathrm{m} R \mathrm{NA}$ and delta receptor binding as defined by the selective ligand [ $\left.{ }^{3} \mathrm{H}\right] \mathrm{D}-\mathrm{Pen}^{2}-\mathrm{Pen}$-enkephalin. Delta receptor $\mathrm{mRNA}$ and binding were expressed in the neocortex, caudate-putamen, nucleus accumbens, olfactory tubercle. diagonal band of Broca. amygdala and the nucleus of the solitary tract. Discrepancies in the distribution of delta receptor mRNA and binding in the olfactory bulb, hippocampus, globus pallidus and substantia nigra pars reticulata, may in part be due to differential receptor synthesis and transport. These results are discussed in relation to the distribution of proenkephalin $\mathrm{mRNA}$ and how this may affect our understanding of opioid circuitry in the CNS.
\end{abstract}

kEY WoRIS: Endorphin Localization Receptor autoradiography In sim hybridization

\section{INTRODUCTION}

The opioid receptors can be classified into three distinct receptor types referred to as $\mu, \delta$ and $k$. Each receptor has a unique distribution in the central nervous system (CNS), a specific pharmacological profile, and has been associated with specific functions (Wood, 1982; Simon, 1991; Lutz and Pfister. 1992; Mansour and Watson, 1993). Mu receptors. which are particularly enriched in the striatum. thalamus. hippocampus, the nucleus of the solitary tract and spinal cord, have been associated with analgesia, respiratory and cardiovascular functions. as well as a number of hormonal actions. Delta receptors, expressed at high levels in many forebrain areas, including the olfactory bulb, neocortex. striatum, hippocampus and amygdala, in addition to the midbrain pontine nuclei and the dorsal horns of the spinal cord. have been associated with analgesia, gastrointestinal motility and hypothalamic regulation. Kappa receptors, the third opioid

*Address correspondence lo: D) A. Mansour. Mental Health Research Institute, Universily of Michigan, 205 Zina Pitcher Place, Ann Arbor, MI 48109 0720. USA. receptor type in the CNS, are expressed at low levels in rodents, but are relatively enriched in the nucleus accumbens, hypothalamus, amygdala, and parallel the $\mu$ distribution in the brainstem and spinal cord. Kappa receptors have been strongly associated with analgesia and in maintaining water balance, in addition to other neuroendocrine functions and behaviors (Leander 't al. 1985; Iyengar 't al. 1986; Manzanares et al., 1990). Within each receptor type, several investigators have suggested multiple receptor subtypes (Goodman and Pasternak, 1985; Nock e' al.. 1988; Zukin et al. 1988: Clark 't al.. 1989: Jang et al., 1991: Sofuoglu et al., 1991).

The three opioid receptor systems in the CNS can be stimulated by one or more of the opioid peptide products derived from the three opioid peptide families: pro-opiomelanocortin (POMC). proenkephalin (PENK) and prodynorphin (PDYN). Several opioid products are hiosynthetically cleaved in the processing of these precursors and can potentially interact with the opoid receptors. Proenkephalin products have the highest affinity for deltat receptors. but can also bind to $\mu$ sites (Davis et al. 1985). (3-endorphin, a POMC-derived peptide 

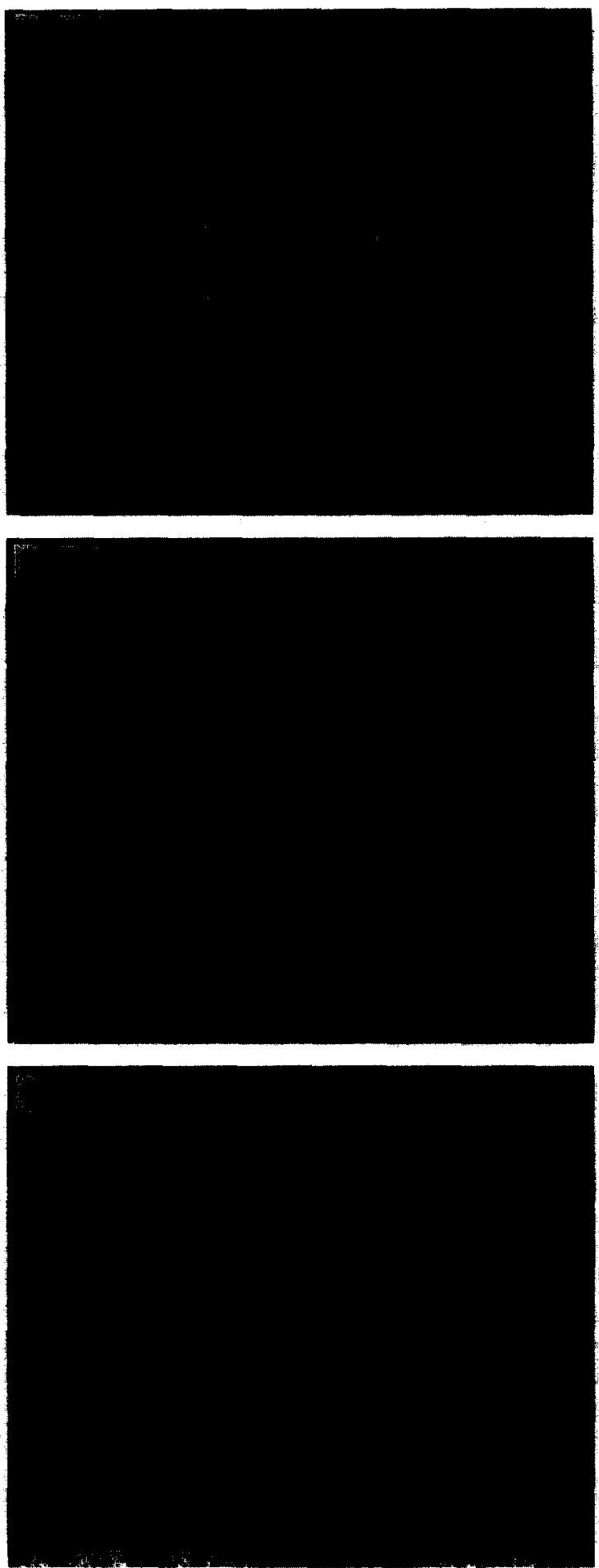

Fig. 1. Darkfield autoradiograms comparing the distribution of delta receptor binding (top), mRNA (middle) and proenkephalin mRNA (bottom) in the mouse olfactory bulb. Delta receptor and proenkephalin mRNAs are localized in the internat granular layer (IGr). where the receptor and peptide are synthesized, while delta receptor binding is predominantly in the terminals of the exterior plexiform layer. Size bar in bottom panel $=500 \mu$

product, binds equally well to $\mu$ and $\delta$ receptors and possibly to a novel epsilon receptor (Shook et al., 1988). Prodynorphin products, such as $\beta$-neoendorphin and dynorphin 1-13, have high affinity for kappa receptors (Chavkin et al., 1982); however, shorter PDYN products appear to bind well to other opioid receptors, particularly in the rat brain where there is a predominance of $\mu$ and $\delta$ sites (Quirion and Pert, 1981; Wüster et al., 1981; Schultz et al., 1982).

To date, the vast majority of data concerning the distribution of the opioid receptors have been derived from receptor binding and autoradiographic studies (McLean et al., 1986; Mansour et al., 1987; Tempel and Zukin, 1987; Sharif and Hughes, 1989). The recent cloning of the mouse delta receptor (Evans et al.. 1992; Kieffer et al., 1992) makes it possible to use a host of new anatomical and biochemical approaches to study delta opioid receptor structure, distribution and regulation. The mouse delta receptor, a 372 amino acid protein, is a member of the seven transmembrane G-protein coupled super-family of neurotransmitter receptors which includes the muscarinic, dopaminergic, noradrenergic and serotoninergic receptors and the bovine opsins (Trumpp-Kallmeyer et al., 1992). Other peptidergic receptors, such as substance $P$, cholecystokinin and somatostatin are also members of this super-family. The delta opioid receptor is negatively coupled to adenylyl cyclase and, based on Northern analysis, may be encoded by multiple mRNA transcripts of varying sizes (Evans et al., 1992).

As the delta receptor was cloned from an NG108 cell line, it is unclear whether it represents the delta receptor expressed in brain. To characterize this receptor further it is therefore important to define its distribution at a cellular level in the CNS and compare it to the distribution of delta receptor binding and proenkephalin mRNA. Previous distribution results have been limited to Northern blot analysis which does not provide the anatomical resolution necessary for such comparisons. The goals of this study were therefore three-fold: (1) to develop the procedures necessary to visualize delta receptor mRNA using in situ hybridization techniques; (2) to compare the mRNA distribution of delta receptor as determined by in situ hybridization to the delta receptor binding sites as defined by the delta selective ligand $\left[{ }^{3} \mathrm{H}\right]$ D-Pen ${ }^{2}-\mathrm{Pen}^{5}$-enkephalin $\left({ }^{3} \mathrm{H}\right]$ DPDPE $)$. Based on findings with other receptors (e.g., Mansour et al., 1991), one would expect that some regions would express both the delta receptor mRNA and binding sites, suggesting local receptor synthesis, while others would exhibit a mismatch, suggesting possible receptor transport; and (3) to compare the delta receptor $m$ RNA distribution to that of PENK mRNA in adjacent sections. Such a comparison potentially provides a means of identifying local opioid circuits.

\section{MATERIALS AND METHODS}

\section{Tissue preparation}

Adult male Swiss Webster mice (Charles River, $20-25 \mathrm{~g}$ ) were sacrificed by cervical dislocation 

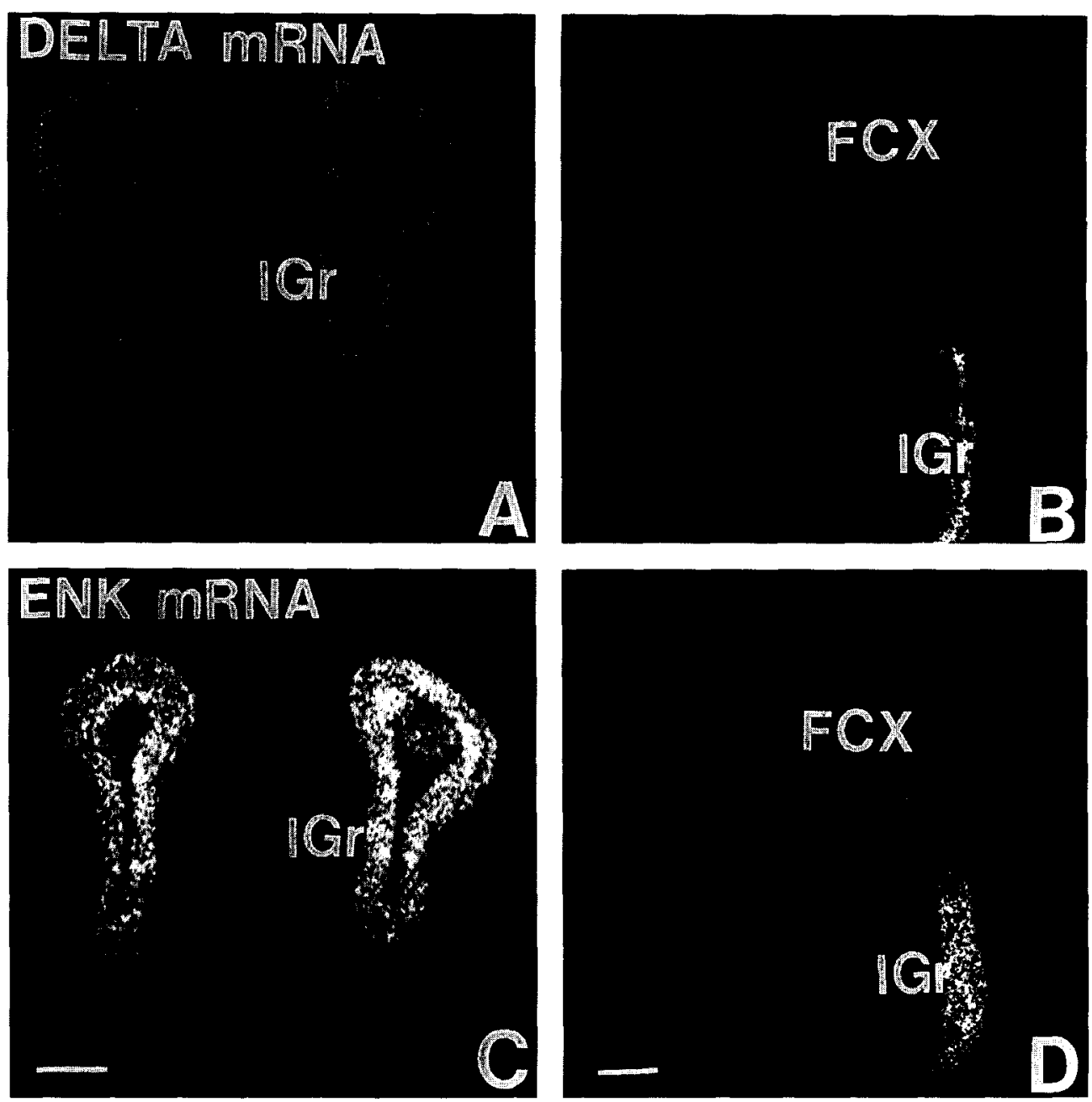

Fig. 2. Darkfield autoradiograms comparing the distribution of delta receptor mRNA and proenkephatin mRNA in the internat granulat layer (IGr) of the olfactory bulb and the frontal cortex (FCX). Note the widespread distribution of delta recepter $m R \backslash A$ apresiten in frontal cortex, compared with the more restricted distribution of proenkepialin. Size bars in $C$ and $D=5(00 \mu$

followed by decapitation. The brains were then dissected and frozen in liquid isopentane $(-30 \mathrm{C})$ for $20 \mathrm{~s}$ and transferred to dry ice. Frozen brains were stored at $-80^{\circ} \mathrm{C}$ until sectioning on a Bright cryostat $(15 \mu)$. Brain sections were thaw-mounted on precleaned and polylysine-subbed microscope slides and stored at $-80^{\circ} \mathrm{C}$.

\section{In situ hybridization}

Frozen brain sections were removed from storage at $-80 \mathrm{C}$ and placed into $4 \%$ formaldehyde for $60 \mathrm{~min}(22 \mathrm{C})$ prior to processing for in situ hybridization (Mansour et al., 1991). Following three 5 -min rinses in $2 \times \mathrm{SSC}(300 \mathrm{~mm}$-sodium chloride, $30 \mathrm{~mm}$-sodium citrate, $\mathrm{pH}=7.2$ ), sections were treated with proteinase $\mathrm{K}(1 \mu / \mathrm{ml}$ in $100 \mathrm{~mm}$ Tris, $\mathrm{pH}=8.0,50 \mathrm{~mm}$-EDTA) for $10 \mathrm{~min}$ at $37 \mathrm{C}$. Slides were then rinsed in water, followed by $0.1 \mathrm{M}$ tricthanolamine, $\mathrm{pH}=8.0$, and treated with a mixture of $0.1 \mathrm{M}$-triethanolamine, $\mathrm{pH}=8.0$, and acetic anhydride $(400: 1, \mathrm{vol} / \mathrm{vol})$ with stirring for
10 min. The sections were then rinsed in water and dehydrated through graded alcohols, and allowed to air dry.

Mouse brain sections were hybridied with $\left[{ }^{35}\right.$ S]UTP and $\left[{ }^{35}\right.$ S]CTP riboprobes generated either to the mouse delta receptors (Evans ('t al. 190)?: Kieffer et al., 1992) or rat PENK mRNA (Yoshitawa 't al. . 1984). The delta receptor cR NA was gencrated from a polymerase chain reaction fragment which is complementary to at 431 bp fragment of the deltat receptor $(472903 \mathrm{bp})$ and corresponds to transmembranes III VI. Proenkephalin mRNA was labeled with a cRNA probe that corresponded to exon 3 (139 $832 \mathrm{bp})$. cRNA probes were diluted in hybridization buffer $\left(75^{\circ} \%\right.$ formamide. $10^{\circ} \%$ dextran sulfate. $3 \times \mathrm{SSC}, 50 \mathrm{~mm} \mathrm{Na}, \mathrm{PO}, \mathrm{pH}=7.4$. $1 \times$ Denhardt's, $0.1 \mathrm{mg} / \mathrm{ml}$ yeast IRNA. $10 \mathrm{~mm}$ dithiothreitol) to result in a final concentration of $1-2 \times 10^{h} \mathrm{cpm} 30 \mu \mathrm{l}$. Volumes of 40 or $100 \mu 101$ diluted probe were applied tocoronal and horizontal sections. respectively. Glass coverslips were plated over brain sections to keep hybridisation huffer 
354 A. Mansour elal.

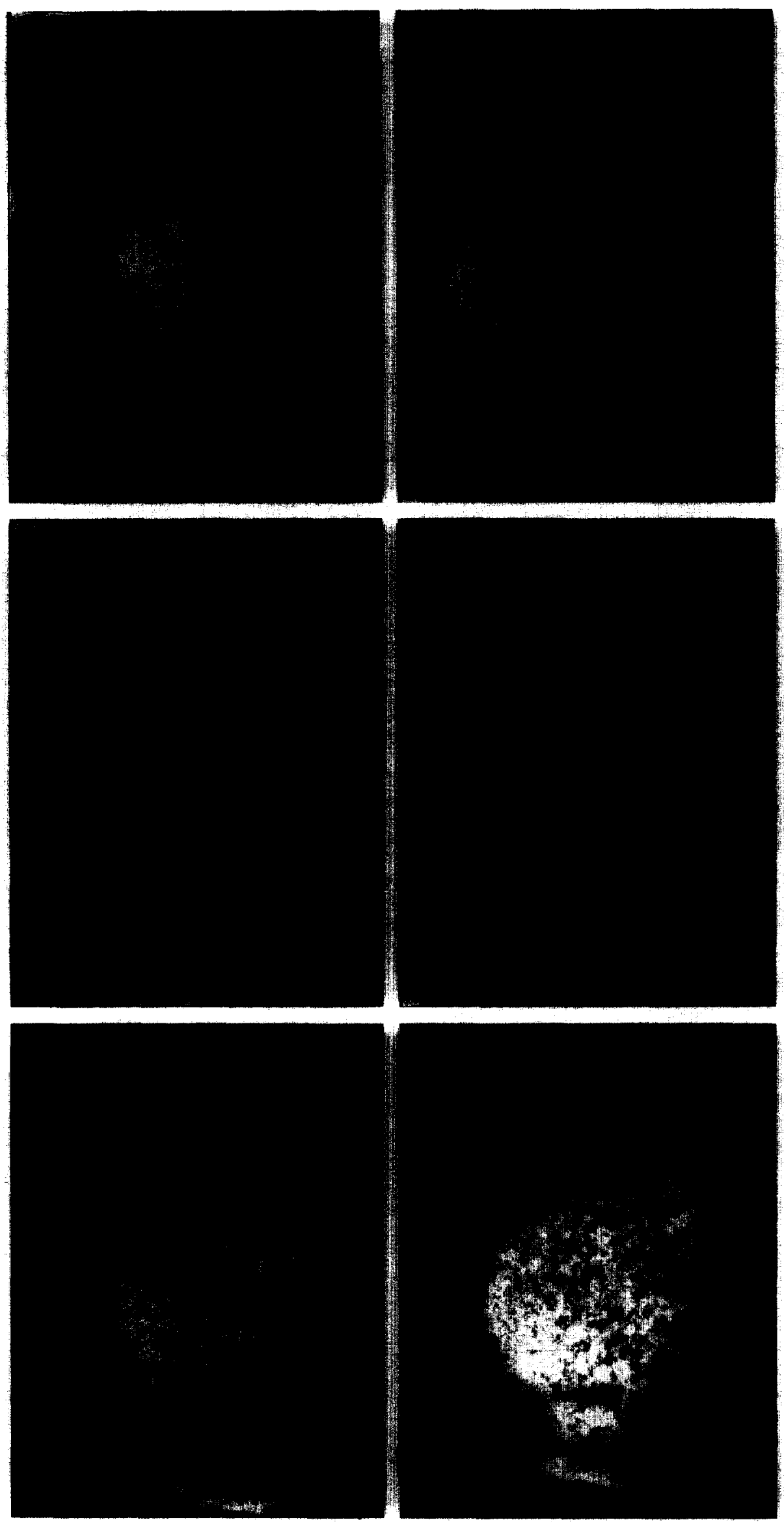


in contact with tissue. The treated slides were transferred to humidifying chambers containing $50 \%$ formamide and hybridized at $55^{\circ} \mathrm{C}$, overnight.

The next day the slides were rinsed in $2 \times \mathrm{SSC}$ $(5 \mathrm{~min})$ and treated with RNase A $(200 \mu \mathrm{g} \mathrm{ml}$ in $100 \mathrm{~mm}$-Tris, $\mathrm{pH}=8.0$, and $0.5 \mathrm{M}-\mathrm{NaCl}$ ) for $60 \mathrm{~min}$ at $37 \mathrm{C}$. Subsequently, the sections were rinsed in $2 \times \mathrm{SSC}$ for $5 \mathrm{~min}\left(22^{\circ} \mathrm{C}\right)$ and $0.1 \times \mathrm{SSC}$ for $60 \mathrm{~min}$ $\left(65^{\circ} \mathrm{C}\right)$. Following the low salt wash, sections were rinsed in water and dehydrated through graded alcohols and air-dried. Sections were apposed to Kodak XAR-5X-ray film for 1-11 days or dipped in NTB2 film emulsion and developed 3-33 days later.

\section{'Sense'-strand control}

The specificity of the in situ signal was tested by hybridizing adjacent mouse brain sections with "sense"-strand CRNA probes generated to the same region of the mouse delta receptor. A series of adjacent brain sections at various levels of the mouse brain were divided into two sets. One set was treated according to the in situ hybridization protocol described above, while the second set was treated identically, except that the cRNA probe used in the hybridization mixture corresponded to the 'sense'-strand.

\section{Delta receptor autoradiography}

After being warmed to room temperature, the brain sections were placed in incubation chambers designed to maintain ambient temperature $\left(22^{\circ} \mathrm{C}\right)$ and humidity $(60-80 \%)$ and incubated with 150 $300 \mu \mathrm{l}$ of $\left[{ }^{3} \mathrm{H}\right]$ ligand and buffer. The selective delta receptor ligand $\left[{ }^{3} \mathrm{H}\right] \mathrm{DPDPE}(28 \mathrm{Ci} / \mathrm{mmol}$, Amersham) was diluted in $50 \mathrm{~mm}-\mathrm{Tris}(\mathrm{pH}=7 \cdot 4)$ to a concentration of $10.2 \mathrm{nM}$. From previous saturation experiments in this laboratory using slide-mounted mouse brain sections it had been determined that this concentration corresponds to 2.5 times the $K_{\mathrm{d}}$ of $\left[{ }^{3} \mathrm{H}\right] \mathrm{DPDPE}$ in the mouse (unpublished observation). The slides were incubated (22 C) for $60 \mathrm{~min}$, drained, and washed in four consecutive $2 \mathrm{~min} 50 \mathrm{~mm}$-Tris washes $\left(\mathrm{pH}=7.0,4^{\circ} \mathrm{C}\right)$. The slides were then rinsed in water $\left(4^{\circ} \mathrm{C}\right)$, dried with a portable hair dryer set to cool and apposed to tritum-sensitive hyperfilm (Amersham) for 60 days. Non-specific binding was evaluated by treating a parallel set of slides with the same concentration of tritiated ligand with a $1 \mu \mathrm{M}$ final concentration of unlabeled Try-D-Ser-Gly-Phe-Leu-Thr.

\section{RESULTS}

A high level of correspondence is observed between the distribution of delta receptor $m R N A$ and $\left[{ }^{3} \mathrm{H}\right] \mathrm{DPDPE}$ binding in a number of telencephalic regions, including the neo- and palcocortex. caudate-putamen, nucleus accumbens, olfactory tubercle, diagonal band of Broca, hippocampus. amygdala and the nucleus of the solitary tract. In the olfactory bulb, a region of high delta receptor expression, delta receptor mRNA is restricted primarily to the internal granular cell layer (Fig. I, $2 \mathrm{~A}$, B), while delta receptor binding is predominantly in the exterior plexiform layer. with only a low density of sites in the internal plexiform and granular cell layers (Fig. 1). Proenkephalin mRNA is restricted to the granular cell layer as seen with the delta receptor mRNA and in the glomerular layer.

Both neo- and paleocortical areas express delta receptors and PENK mRNA. Delta receptor mRNA is distributed in a similar laminar pattern as observed with delta binding sites (Figs 3 and 4), with the receptor $\mathrm{mRNA}$ predominantly in layers II. III. $\mathrm{V}$ and VI of frontal, parietal and temporal cortex. Similarly, PENK mRNA is localized in the neocortex, but its distribution is not as widespread, being restricted primarily to layers II and VI (Figs 24 ). In contrast to the delta receptor $\mathrm{mRNA}$, which is relatively enriched in neocortical areas. PENK mRNA is more robustly expressed in paleocortical areas, such as the cingulate and piriform cortex (Fig. $4 \mathrm{E}, \mathrm{F}$ ), with only low levels of expression in the frontal, parietal and temporal cortex. Compare, for example, Fig. 2 (B, D), where delta receptor mRNA is widely distributed in frontal cortex and PENK $m$ RNA is restricted to layers II and VI, to Fig. 4, where PENK mRNA is prominent in piriform and cingulate cortex (Fig. 4E, F) and delta receptor $m$ RNA and binding is most prominent in the parietal. frontal and cingulate corlex (Fig. 4A-D).

In the basal ganglia, delta receptor binding and mRNA share a similar distribution in the caudateputamen, nucleus accumbens and olfactory tubercle. Relatively high levels of delta receptor $m$ RNA and binding are seen in the caudate-putamen, both showing a medial to lateral gradient with the highest levels in the lateral portion of this structure (Fig. $3 A-D)$. In the nucleus accumbens, the highest levels of expression of both delta receptor mRNA and $\left.{ }^{3} \mathrm{H}\right] \mathrm{DPDPE}$ binding are seen in the ventral portions of the anterior shell (Fig. 3A, C) with comparatively lower levels of $\mathrm{mRNA}$ and binding in the core. More

Fig. 3. Darkfield autoradiograms comparing delta receptor binding, mRNA and proenkephalin mRNA distributions at two levels of the forebrain of the mouse. Delta receptors and proenkephalin mRNA is expressed in the caudate-putamen (CPU), nucleus accumbens (ACB), olfactory tubercle (OTU) and diagonal band of Broca (DB). Delta receptors are particularly high in the neocortical areas, such as the parietal cortex (PCX), while proenkephalin $\mathrm{MRNA}$ is predominantly in paleocortical regions, such as piriform cortex (Pir). Size bar in $\mathrm{F}=500 \mu$. 


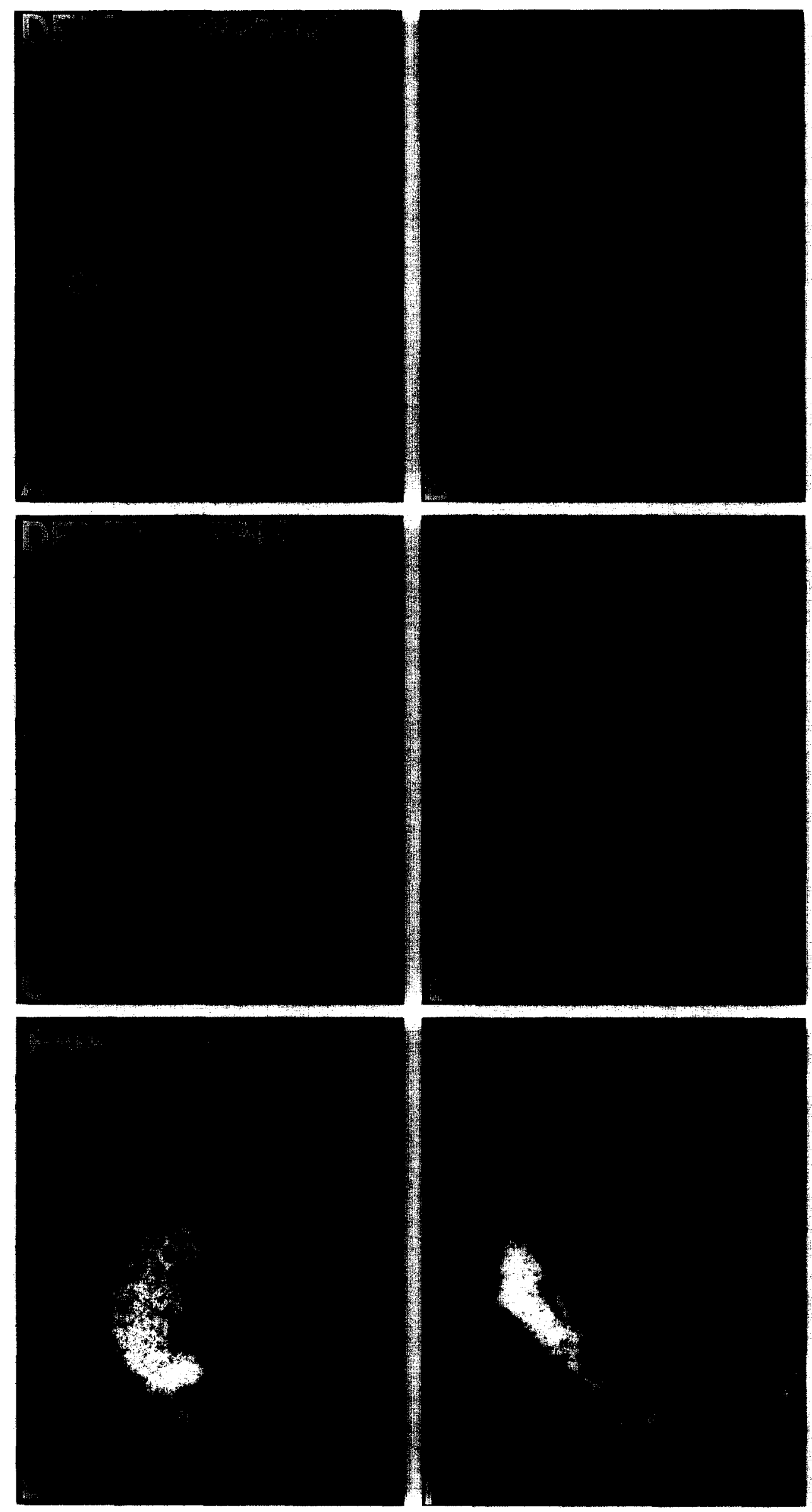



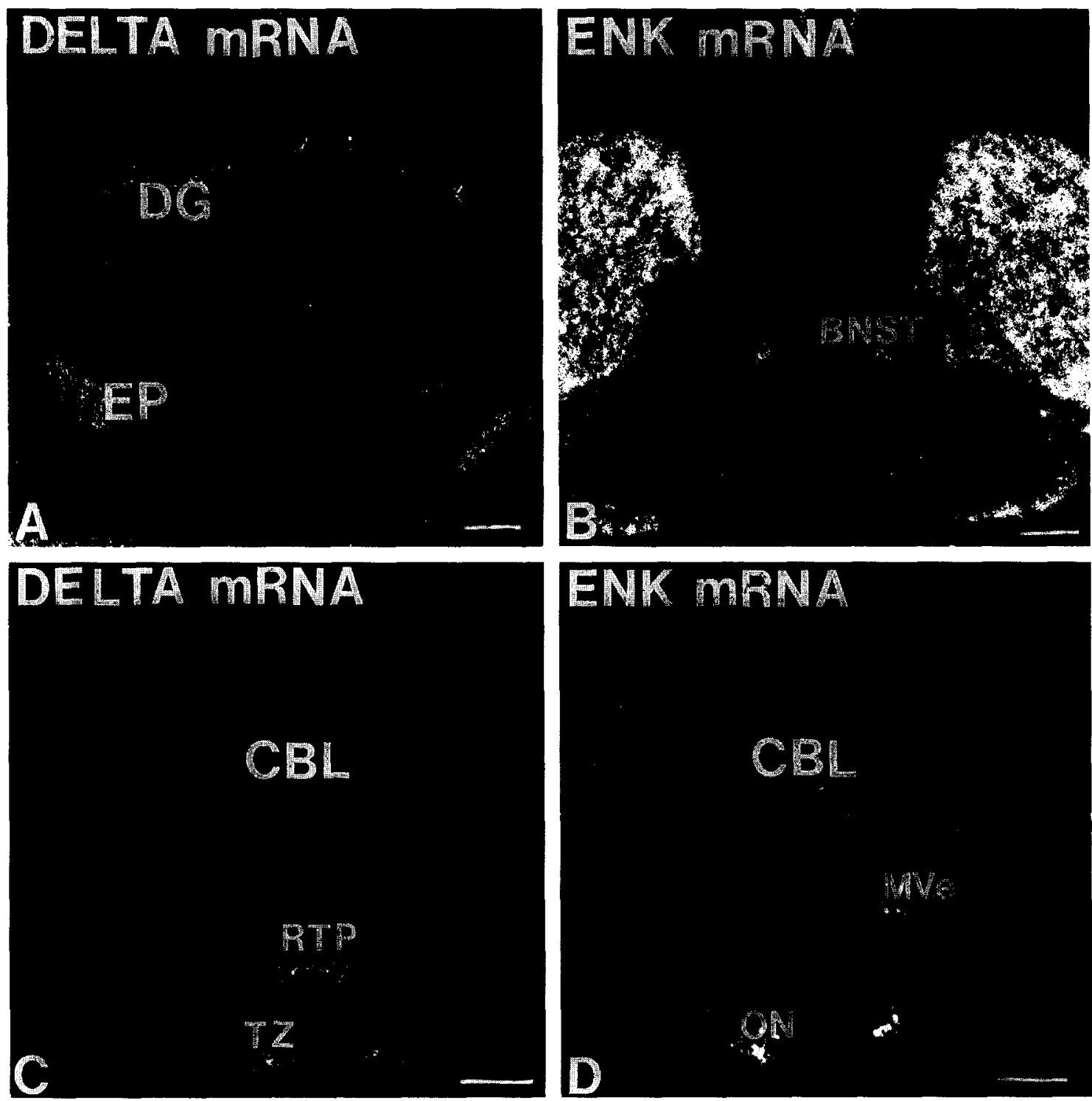

Fig. 5. Darkfield autoradiograms demonstrating regions of differential expression of delta receptor $m R N A$ and proenkephalin $m R N \Lambda$. Delta recentor mRNA can be visualized in the entopeduncular (EP), reticulotegmental pontine (RTP) and trapazoid (TZ) nuclei. areas that do not express proenkephatin mRNA. Proenkephalin mRNA is localized in the medial preoptic area. bed nucleus stria terminalis (BNST), ccrebellum (CBL). medial vestibular (MVe) and olivary $(O N)$ nuclei, areas with no delta receptor expression. Size bars : $=5(6) \mu$

ventrally, the olfactory tubercle expresses relatively high levels of delta receptor $\mathrm{mRNA}$ and binding (Fig. 3A D). Consistent with the delta receptor distribution. PENK mRNA displays a similar medial to lateral expression gradient in the caudateputamen. with the highest levels laterally (Fig. 3E, F). The nucleus accumbens and olfactory tubercle also show high levels of PENK mRNA expression with high levels in the accumbens shell and core and throughout the olfactory tubercle (Fig. 3E. F).
In the globus and ventral pallidum. there is a low density of delta receptor binding sites and no detectable delta receptor $m$ RNA. suggesting that the binding may be localized on terminals. No PENKexpressing cells are seen in the globus pallidus, but scattered PENK-expressing cells are found in the ventral pallidum.

The diagonal band of Broca shows an excellent correspondence between delta receptors and PENK mRNA. suggesting the presence of a local opioid

Fig. 4. Darkfield comparison of delta receptor binding, mRNA and proenkephalin mR NA at two levels of the diecephalon. Delta receptor binding and mRNA can be visualized in the cortex (CTX), pvramidal cell layer of the hippocampus (CA1. CA2). dentate gyrus (I)G), caudate-putamen (CPU) and basolateral amygdala (BLA). Proenkephalin $\mathrm{m}$ RA is prominent in the caudate-putamen. piriform cortex (Pir). central and medial amygdala (ME) and dorsomedial hypothalamus (DMH). Only a few proenkephalin-expressing cells areobserved in the basolateral amygdala. Size bar in $F=500 \mu$ 


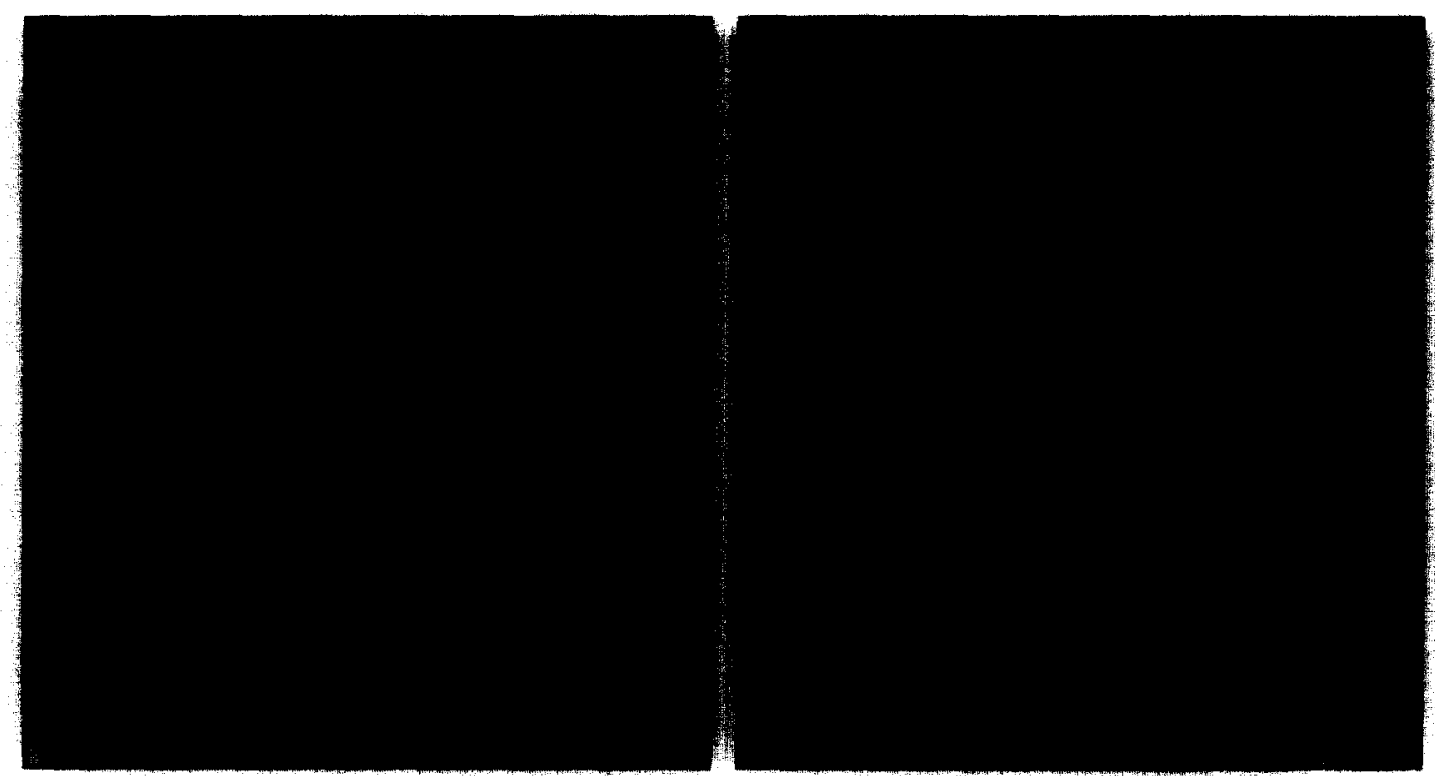

Fig. 6. Darkfield autoradiograms comparing the distribution of delta receptor binding and mRNA in the mouse midbrain. Note the delta receptor mRNA and binding in the pontine nuclei $(\mathrm{Pn})$ and entorhinal cortex (Ent)). Size bar in $B=500 \mu$.

circuit (Fig. 3B, D, F). Delta receptor binding, mRNA, and PENK mRNA are observed in the rostral diagonal band of Broca extending caudally to the horizontal limb.

In the hippocampus, delta receptor binding sites and mRNA are localized in the pyramidal cell layer (Fig. 4A-D). Delta receptor binding extends beyond the pyramidal layer with binding observed in the stratum lacunosum-moleculare, a region receiving terminal projections from the pyramidal cells, suggesting possible receptor transport (Fig. 4A, B). Delta receptor mRNA is also localized in the granular cell layer of the dorsal dentate gyrus (Fig. 4C, D), while delta receptor binding sites are observed in both the granular and molecular layers. Low levels of PENK mRNA are seen in the pyramidal cell layer of the hippocampus and the granular layer of the dentate gyrus, possibly consistent with a local opioid circuit. As the levels of PENK mRNA in the hippocampus and dentate gyrus are extremely low compared with the striatum, specifically labeled cells are not apparent in these structures with this film exposure.

In the amygdaloid complex, there is a good correspondence between delta receptor mRNA and binding, with high levels of both in the lateral and basolateral nuclei (Fig. 4A-D). The cortical and medial nuclei also have moderate levels of delta receptor binding, with the cells expressing delta receptor mRNA predominantly in the cortical nucleus. In contrast, high levels of PENK mRNA are observed in the medial and central amygdala nuclei (Fig. 4E, F), regions demonstrating little or no delta receptor binding and mRNA. Further, the basolateral nucleus of the amygdala has only a few, if any, PENK-expressing cells, yet has the highest levels of delta receptors in the amygdaloid complex.
Discrepancies between the distributions of PENK mRNA, delta receptor binding and delta receptor mRNA are also particularly apparent in the diencephalon. Several hypothalamic nuclei, including the paraventricular, dorsomedial, ventromedial nuclei and the lateral hypothalamic area express high levels of PENK mRNA, yet only the ventromedial nucleus demonstrates a low density of delta receptor binding and cells expressing delta receptor mRNA. Similarly, the bed nucleus stria terminalis and the medial preoptic area (Fig. 5B) contain cells expressing PENK mRNA, yet in the mouse have little or no delta receptors.

Several nuclei of the thalamus, including the central medial, medial dorsal and ventromedial nuclei demonstrate low levels of delta receptor binding and no detectable delta receptor mRNA. This is also evident in a number of midbrain regions, such as the interpeduncular nucleus, substantia nigra (pars reticulata) and periaqueductal grey, where low levels of delta receptor binding are clearly observed, with no detectable delta receptor mRNA, suggesting a possible differential localization of binding sites on neuronal terminals. The reverse is observed in the entopeduncular nucleus, where relatively high levels of delta receptor mRNA (Fig. 5A) and no detectable receptor binding or PENK mRNA are observed. Consistent with the presence of delta receptor binding sites, PENK-expressing cells are localized in the periaqueductal grey and interpeduncular nucleus.

In the pontine nuclei, an excellent correspondence between delta receptor mRNA and binding is observed (Fig. 6). This region contains no PENK-expressing cells and demonstrates another clear mismatch between the distribution of PENK mRNA and delta receptor binding and mRNA. The 

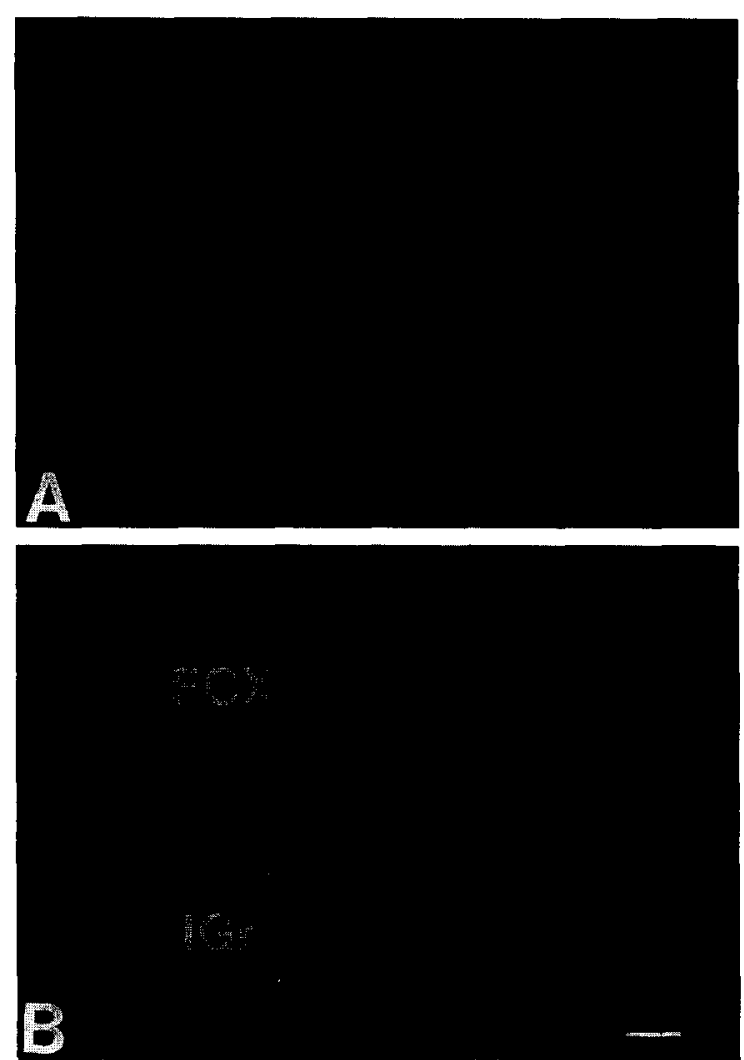

Fig. 7. 'Sense'-strand control. Note the lack of specific in situ hybridization in frontal cortex (FCX) and the internal granular layer (IGr) when a 'sense'-strand probe is used (A) as compared with an antisense $c R N A$ probe $(B)$ generated to the same region of the mouse delta receptor. Size bar in $\mathrm{B}=500 \mu$.

converse is observed in the raphe nuclei, where there are high levels of PENK mRNA expression in the dorsal. median and linear raphe and no detectable delta receptors.

More caudally, delta receptor mRNA is seen in the reticular tegmental pontine, trapazoid nuclei (Fig. 5C) and the nucleus of the solitary tract. Specific del ta receptor binding is difficult to detect in the brainstem and only observed at low levels in the nucleus of the solitary tract. No delta receptor mRNA or binding is seen in the cerebellum. In contrast. PENK mRNA expression is extensive throughout brainstem and cerebellum (Fig. 5D). Nuclei expressing PENK mRNA and no detectable delta receptors include the parabrachial, medial vestibular, dorsotegmental, lateral reticular, cochlear and olivary nuclei (Fig. 5D).

\section{'Sense'-strand control}

The results of the 'sense'-strand control experiment are presented in Fig. 7. In situ hybridization of brain sections with a "sense' cRNA probe generated to the same region of the delta receptor produced no specific hybridization. Compare, for example, the lack of labeling of cells in the frontal cortex and internal granular layer of the olfactory bulb when a "sense'-strand cRNA probe is used (Fig. 4A).

\section{DISCUSSION}

Generally, there is an excellent correspondence between the distribution of the delta receptor mRNA and delta receptor binding as defined by $\left[{ }^{3} H\right]$ DPDPE. Several brain regions. including the neocortex, caudate-putamen, nucleus accumbens, olfactory tubercle, diagonal band of Broca, amygdala, pontine nuclei and nucleus of the solitary tract demonstrated both delta receptor binding and receptor mRNA, providing the first cellular localization of this $\mathrm{mRNA}$ in the CNS. This receptor mRNA distribution agrees well with other studies describing delta receptor binding sites (Moskowitz and Goodman, 1985: McLean et al., 1986: Mansour et al. 1987: Tempel and Zukin, 1987; Sharif and Hughes, 1989) and is consistent with this receptor representing a brain delta receptor.

Despite a general correspondence between the distributions of delta receptor mRNA and binding. clear differences were also observed. These discrepancies or mismatches are manifest in one of two ways: the presence of delta receptor binding and no mRNA. or the localization of delta receptor mRNA and no binding sites. In some cases, as in the hippocampus and olfactory bulb, this may be an indication of differential receptor synthesis and transport. In the olfactory bulb, for example, delta receptor mRNA and synthesis is in the cell bodies of the internal granular cell layer, while delta receptor binding sites are predominantly on the cell terminals in the exterior plexiform layer. Similarly, in the hippocampal formation. delta receptor $m R N A$ and synthesis is in the pyramidal cell layer. while the binding sites are localized in the pyramidal layer and extend to the terminals in the molecular layer.

Other regions demonstrating a lack of correspondence between delta receptor binding and mRNA include substantia nigra pars reticulata, and globus pallidus, where low levels of binding and no delta receptor mRNA could be detected. Here, too, these binding sites may be localized on terminals from cells in the striatum that project to the globus pallidus and substantia nigra pars reticulata. Kainic acid lesions that destroy cell bodies of the striatum, in fact, produce a loss of delta receptor binding in the globus pallidus and substantia nigra. pars resticulata, which is consistent with these binding sites being localized on presynaptic terminals (Abou-Khalil et al., 1984; Van Der Kooy et al., 1986).

Delta receptor mRNA but no detectable delta receptor binding was found in the entopeduncular, reticular pontine and trapazoid nuclei. The entopeduncular nucleus has efferent projections to the thalamus, particularly the ventromedial nucleus. where low levels of delta receptor binding and no receptor $m R N A$ are observed. The delta receptors may, therefore, be synthesized in the entopeduncular nucleus and transported to the thalamus 
explaining the discrepancy between the receptor binding and in situ hybridization results. The presence of delta receptor mRNA and no delta receptor binding in the reticular pontine and trapazoid nuclei is more difficult to explain as the reticular pontine primarily projects to the cerebellum and the trapazoid nucleus projects mainly to the lateral olive, regions that have no detectable delta receptor binding.

Receptor transport is only one of many possible explanations for a discrepancy between the distribution of the delta receptor mRNA and binding sites. There may be, for example, several delta receptor subtypes (Jiang et al., 1991; Sofuoglu et al., 1991). Our in situ hybridization methods and cRNA probes may be visualizing multiple delta receptor subtypes and $\left[{ }^{3} \mathrm{H}\right] \mathrm{DPDPE}$ may be labeling more than one delta receptor protein. Northern blot analysis has demonstrated as many as five transcripts that could encode delta receptors (Evans et al., 1992) in NG108 cells. It is presently unclear whether they represent alternate splice forms of the same gene or different gene products. The future cloning of other delta receptor cDNAs and genes will be necessary in order to resolve this issue.

Another possible explanation for the discrepancies observed between delta receptor binding and mRNA in some regions may be the detection limits of either the receptor autoradiographic or in situ hybridization methods. Regions such as the thalamus that have very low levels of binding may also have low levels of delta receptor mRNA expression which may be beyond the limits of our methods. Similarly, in the brainstem nuclei, where specific delta receptor binding is very low, it is difficult to differentiate it from background, accounting for the presence of delta receptor $\mathrm{mRNA}$ and no detectable binding.

Comparison of the delta receptor $\mathrm{mRNA}$ and binding to the distribution of PENK mRNA (Harlan et al., 1987) showed that while there were some regions, such as the striatum, olfactory tubercle, diagonal band of Broca and the nucleus of the solitary tract that showed a good correspondence, the vast majority of brain areas failed to show a similar localization of PENK mRNA and delta receptors. A co-distribution of PENK $M R N A$ and delta opioid receptors may indicate either an autoreceptor function, as may be the case in the granular cells of the olfactory bulb. Or, alternatively, it is consistent with local opioidergic circuits via collaterals, as in the striatum, or direct projections, as may be the case in the diagonal band of Broca. While these results are suggestive, specific synapses and circuits need to be verified by more extensive immunohistochemical and electron microscopic studies.

Clear dissociations between the distributions of PENK mRNA and delta receptors were observed in the hypothalamus, medical preoptic area, bed nucleus stria terminalis, central amygdala, raphe nuclei and cerebellum, as well as a number of brain- stem nuclei, including the parabrachial, dorsotegmental, lateral reticular, cochlear, and olivary nuclei where PENK mRNA was expressed and no delta receptor $m R$ NA could be visualized. The reverse was also apparent in the basolateral amygdala, pontine and trapazoid nuclei, where delta receptor mRNA is expressed and no PENK mRNA could be visualized.

This apparent peptide-receptor mismatch has been extensively discussed by others (Kuhar, 1985; Herkenham and McLean, 1986), and this study provides further support that in many brain regions PENK-derived peptides are unlikely to interact directly with delta receptors. However, these data need to be interpreted with caution for several reasons. First, this study does not provide information concerning enkephalinergic terminals and projections which are critical in interpreting these results. Many brainstem nuclei, such as the parabrachial nucleus that express PENK mRNA project rostrally, and may interact with delta receptors in the diencephalin, for example. Immunohistochemical studies directly visualizing opioid peptides and receptors with selective antibodies are needed in the future to evaluate this possibility properly. Second, peptide products from other opioid precursors (POMC, PDYN) have good affinity for delta receptors in binding studies, and may interact with delta receptors anatomically. One example is in the neocortex where PENK-expressing cells are restricted primarily to layers II and VI, while delta receptor binding and $\mathrm{mRNA}$ is prominent in layers II, III, V and VI. Prodynorphin-expressing cells have a more widespread distribution in the rat neocortex (Alvarez et al., 1990), suggesting that dynorphin peptides may be released and bind to delta receptor sites under physiological conditions. Third, there may be multiple delta receptors that remain to be cloned, that may have a better codistribution with PENK. And fourth, we may be identifying, in some cases, only the cells expressing the delta receptor mRNA at the highest levels, thereby contributing to the apparent mismatch.

In summary, this study demonstrates that the delta receptor binding sites and mRNA show a similar distribution in the mouse central nervous system and regions of discrepancy may be due, in part, to differential receptor synthesis and transport. Similar studies need to be extended to the rat. Species differences at the nucleic acid level have presumably made it difficult to detect this mRNA using mouse delta receptor $\mathrm{cRNA}$ probes. It is likely that other delta opioid receptors will be cloned in the near future and similar analyses will be needed to determine the functional significance and anatomical distribution of these receptors. Using the derived amino acid sequence of present delta receptor, antibodies can be raised to localize more precisely the delta receptor proteins immunohistochemically and co-localize it with the opioid peptides. 


\section{ACKNOWLEDGEMENTS}

The authors thank Charles Fox and Eileen Curran for their critical reading and helpful discussion of this manuscript, and James Smith and Stephanie McWethy for excellent secretarial contributions. This work was supported by grants from The Markey (haritable Trust, NIDA (DA 02265). NIMH (MH $4225 \mathrm{I}$ ) and the Gastrointestinal Hormone Research Center (P30 AM34933).

\section{REFERENCES}

Abou-Khalil, B.. Young. A. B. and Penney, J. B. (1984). Evidence for the presynaptic localization of opiate binding sites on striatal efferent fibers. Brain Res. $\mathbf{3 2 3}$. 21-29.

Alvarez. B. G., Fairen. A., Douglas, J. and Naranjo, J. R. (1990). Expression of the prodynorphin gene in the developing and adult cerebral cortex of the rat: an in sint hybridization study. I. Comp. Neurol. 300, 287-300.

Chavkin, C., James, I. F. and Goldstein, A. (1982). Dynorphin is a specific endogenous ligand of the $k$ opioid receptor. Science 215, 413-415.

Clark, J. A., Liu. L., Price, M., Hersh, B., Edelson, M. and Pasternak, G. W. (1989). Kappa opiate receptor multiplicity: Evidence for two U50, 488-sensitive $\kappa_{1}$ subtypes and a novel $\kappa_{3}$ subtype. J. Pharmacol. Exp. Ther. 251, $461-468$.

Davis. T. P., Porreca. F., Burks, T. F. and Dray, A (1985). The proenkephalin A fragment, peptide E: Central processing and CNS activity in vivo. Eur. $J$. Pharmucol. 111, $177-183$.

Evans, C. J., Keith, D. E. Jr.. Morrison, H., Magendzo. K. and Edwards, R. H. (1992). Cloning of a delta opioid receptor by functional expression. Science $\mathbf{2 5 8}$, 1952-1955.

Goodman, R. R. and Pasternak, G. W. (1985). Visualization of $\mu_{1}$ opiate receptors in rat brain by using a computcrized autoradiographic subtraction technique. Proc. Natl. Acad. Sci. USA 82, 6667-6671.

Harlan. R. E., Shivers, B. D., Romano, G. H., Howells, R. D. and Pfaff, D. W. (1987). Localization of preprocnkaphalin mRNA in the rat brain and spinal cord by in situ hybridization. J. Comp. Neurol. 258, 159-184.

Herkenham. M. and McLean, S. (1986). Mismatches between receptor and transmitter localizations in the brain. In Quantitative Receptor Autoradiography (eds Boast, C., Snowhill, E. W. and Altar, C. A.). pp. 137 171. Alan R. Liss, New York.

lyengar. S.. Kim. H. S. and Wood, P. L. (1986). Kappa opiate agonists modulate the hypothalamic-pituitaryadrenocortical axis in the rat. J. Pharmacol. Exy. Th'r. $238,429-436$.

Jiang, Q.. Takemori, A. E., Sultana, M.. Portoghese, P. S.. Bowen. W. D., Mosberg, H. I. and Porreca, F. (1991). Differential antagonism of opiod delta antinociception by $\left[\mathrm{D}-\mathrm{Ala}{ }^{2}, \mathrm{Leu}^{5}, \mathrm{Cys}^{6}\right]$ enkephalin and naltrindole $5^{\prime}-$ isothiocyanate: Evidence for delta receptor subtypes. $J$. Pharmacol. Exp. Ther. 257. 1069-1075.

Kieffer, B. L., Befort, K., Gaveriaux-Ruff, C. and Hirth, C. G. (1992). The $\delta$-opioid receptor: Isolation of a cDNA by expression cloning and pharmacological characterization. Proc. Natl. Acad. Sci. USA 89, $12048-12052$.

Kuhar. M. J. (1985). The mismatch problem in receptor mapping studies. Trends in Neurosci, 8, 190-191.
Leander. J. D., Zerbe. R. L. and Hall. J. C. (1985). Diuresis and suppression of vasopressin by kappa opioids: Comparison with mu and della opioids and clonidine. J. Pharmacol. Exp. Th'

Lutz, R. A. and Pfister, H. P. (1992). Opioid receptors and their pharmacological protiles. J. Receptor Res. 12. 267-286.

Mansour, A. and Watson. S. J. (1993). Anatomical distribution of opioid receptors in mammalians: An overview. In Handbook of Experimental Pharmacology. Vol. 1041 Opioids I. (ed. Herz, A.), pp. 79105. Springer-Verlag. New York.

Mansour, A.. Khachaturian, H., Lewis, M. E. Akil, H. and Watson. S. J. (1987). Autoradiographic differentiation of mu. delta. and kappa opioid receptors in the rat forcbrain and midbrain. I. Veuressei. 7, 2445 2464.

Mansour. A., Meador-Woodruff. J. H.. Zhou. Q.-Y.. Civelli, O., Akil, H. and Watson. S. H. (I99). A comparison of $\mathrm{D} /$ receptor binding and $m R N A$ in rat brain using receptor autoradiographic and in situ hybridization techniques. Neuroscience 45. 359371.

Manzanares, J., Lookingland. K. J. and Moore, K. F. (1990). Kappa-opioid-receptor-mediated regulation of a F-melanocyte-stimulating hormone secretion and tuberohypophysial dopaminergic neuronal activity. Ne'uroendocrinology 52,200 205

MeLean. S., Rothman. R. B. and Herkenham. M. ( 986 ). Autoradiographic localization of $\mu$ and $\delta$-opiate receptors in the forebrain of the rat. Brain Re's. 378 , 4960.

Moskowitz, A. S. and Goodman. R. R. (1985). Autoradiographic analysis of MU, MU, and della opioid binding in the central nervous system of $C 57 \mathrm{BL} 6 \mathrm{BY}$ and CXBK (opioid receptor-deficient) mice. Brain Re's. 360, 108.116

Nock. B. Rajpara. A.. O'Connor. L. H. and (icero. T. J. (1988). [ $\left.{ }^{3} \mathrm{H}\right] \mathrm{U}-69593$ labels a sublype of kappa opiate receptor with characteristics different from that labeled by $\left[{ }^{3} \mathrm{H}\right]$ ethylketocylazocine. Lifo Si $i$ 42, 24032412.

Quirion, R. and Pert. C. B. (1981). Dynorphins: similar relative potencies on mu, deltil and kappa opiate receptors. Eur. J. Pharmacol. 76, 467468 .

Schulz. R. Wüster. M. and Hers. A. (1982). Endogenous ligands for K-opiate receptors. Peptide's 3,973 976

Sharif. N. A. and Hughes. J. (1989). Discrete mapping of brain $m u$ and delta opioid receptors using selective peptides: Quantitative autoradiography species differences and comparison with kappa receptors. Peptide's 10, $499-522$.

Shook, J. E.. Kazmierski, W., Wire, W. S., Lemcke. P. K.. Hruby, V. J. and Burks. T. F. (1988). Opioid receptor selectivity of $\beta$-endorphin in vitro and in vire: Mu, delta and epsilon receptors. I. Pharmacol. Exp. Ther. 246, $1018-1025$

Simon. E. H. (1991). Opioid receptors and endogenous opioid peptides. Médicinal Rés. Re'v 11,357 374.

Sofuoglu. M.. Portoghese, P. S. and Takemori. A. E. (1991). Differential antagonism of delta opioid agonists by naltrindole and its benzofuran analog (NTB) in mice: Evidence for delta opioid receptor subtypes. $J$. Pharmacol. E.tp. Ther. 257,676 680.

Tempel, A. and Zukin. R. S. (1987). Neuroanatomical patterns of the $\mu . \dot{\delta}$. and $\kappa$ opioid receptors of rat brain ats determined by quantitative in vitro autoradiography. Proc Natl Acad Sci. LS.4 84, 4308 +312 


\section{A. Mansour et al}

Trumpp-Kallmeyer, S., Hoflack, J., Bruinvels, A. and Hibert, M. (1992). Modeling of G-protein-coupled receptors: Application to dopamine, adrenaline, serotonin, acetylcholine, and mammalian opsin receptors. J. Med. Chem. 35, 3448-3462.

Van Der Kooy, D., Weinreich, P. and Nagy, J. I. (1986). Dopamine and opiate receptors: Localization in the striatum and evidence for their axoplasmic transport in the nigrostriatal and striatonigral pathways. Neuroscience 19, 139-146.

Wood, P. L. (1982). Multiple opiate receptors: Support for unique mu, delta and kappa sites. Neuropharmacology 21, 487-497.
Wüster, M., Rubini, P. and Schultz, R. (1981). The preference of putative pro-enkephalins for different types of opiate receptors. Life Sci. 29, 1219 1227.

Yoshikawa, K., Williams, C. and Sabol, S. L. (1984). Rat brain preproenkephalin mRNA. J. Biol. Chem. 259 , 14301-14308

Zukin, R. S., Eghbali, M., Olive, D., Unterwald, E. M. and Tempel, A. (1988). Characterization and visualization of rat and guinea pig brain $\mathrm{k}$ opioid receptors: Evidence for $\kappa_{1}$ and $\kappa_{2}$ opioid receptors. Proc. Natl. Acad. Sci. USA 85, 4061-4065. 